Article

\title{
Incomplete LPS Core-Specific Felix01-Like Virus vB_EcoM_VpaE1
}

\author{
Eugenijus Šimoliūnas ${ }^{1}$, Monika Vilkaitytė ${ }^{1}$, Laura Kaliniene ${ }^{1}$, Aurelija Zajančkauskaitė ${ }^{1}$, \\ Algirdas Kaupinis ${ }^{2}$, Juozas Staniulis ${ }^{3}$, Mindaugas Valius ${ }^{2}$, Rolandas Meškys ${ }^{1}$ and \\ Lidija Truncaite ${ }^{1, *}$ \\ Received: 8 October 2015; Accepted: 18 November 2015; Published: 27 November 2015 \\ Academic Editor: Rob Lavigne \\ 1 Department of Molecular Microbiology and Biotechnology, Institute of Biochemistry, Vilnius University, \\ Vilnius LT-08662, Lithuania; eugenijus.simoliunas@bchi.vu.lt (E.Š.); m.vilke@gmail.com (M.V.); \\ laura.kaliniene@bchi.vu.lt (L.K.); aurelija.zajanckauskaite@bchi.vu.lt (A.Z.); \\ rolandas.meskys@bchi.vu.lt (R.M.) \\ 2 Proteomics Centre, Institute of Biochemistry, Vilnius University, Vilnius LT-08662, Lithuania; \\ algirdas.kaupinis@gf.vu.lt (A.K.); mindaugas.valius@bchi.vu.lt (M.V.) \\ 3 Laboratory of Plant Viruses, Institute of Botany, Nature Research Centre, Vilnius LT-08412, Lithuania; \\ juozas.staniulis@botanika.lt \\ * Correspondence: lidija.truncaite@bchi.vu.lt; Tel.: +370-5-2729146
}

\begin{abstract}
Bacteriophages represent a valuable source for studying the mechanisms underlying virus-host interactions. A better understanding of the host-specificity of viruses at the molecular level can promote various phage applications, including bacterial diagnostics, antimicrobial therapeutics, and improve methods in molecular biology. In this study, we describe the isolation and characterization of a novel coliphage, vB_EcoM_VpaE1, which has different host specificity than its relatives. Morphology studies, coupled with the results of genomic and proteomic analyses, indicate that vB_EcoM_VpaE1 belongs to the newly proposed genus Felix01likevirus in the family Myoviridae. The genus Felix01likevirus comprises a group of highly similar phages that infect O-antigen-expressing Salmonella and Escherichia coli (E. coli) strains. Phage vB_EcoM_VpaE1 differs from the rest of Felix01-like viruses, since it infects O-antigen-deficient E. coli strains with an incomplete core lipopolysaccharide (LPS). We show that vB_EcoM_VpaE1 can infect mutants of E. coli that contain various truncations in their LPS, and can even recognize LPS that is truncated down to the inner-core oligosaccharide, showing potential for the control of rough E. coli strains, which usually emerge as resistant mutants upon infection by O-Ag-specific phages. Furthermore, VpaE1 can replicate in a wide temperature range from 9 to $49^{\circ} \mathrm{C}$, suggesting that this virus is well adapted to harsh environmental conditions. Since the structural proteins of such phages tend to be rather robust, the receptor-recognizing proteins of $\mathrm{VpaE1}$ are an attractive tool for application in glycan analysis, bacterial diagnostics and antimicrobial therapeutics.
\end{abstract}

Keywords: E. coli lipopolysaccharide; inner core oligosacharide; bacteriophage vB_EcoM_VpaE1 host-range; genus Felix01likevirus; PACS; J0101

\section{Introduction}

Attachment to cell surface receptors is the first step in phage infection. Phages of Gram-negative bacteria use a variety of cell-associated structures including pili, flagella, outer membrane proteins (Omp) or lipopolysaccharides (LPS) for host cell recognition [1-3]. LPS is a major constituent of the bacterial outer membrane (OM). Natural Escherichia and Salmonella isolates usually contain LPS that consists of: (i) the lipid A, a hydrophobic moiety of the molecule that anchors LPS to the OM; (ii) a 
phosphorylated, nonrepetitive hetero-oligosaccharide known as the core oligosaccharide (core OS); and (iii) the O-antigen side chain polysaccharide (O-PS or O-Ag) that is a polymer of defined repeat units attached to the core OS, and is usually used for serotyping [4]. The inner part of the core OS is highly conserved within the Gram-negative bacteria, whereas the outer core is more diverse, and the $\mathrm{O}-\mathrm{Ag}$ is the most variable moiety $[5,6]$.

As mentioned previously, a number of bacteriophages use LPS as a receptor for attachment to the host cell. In turn, as the response to a strong selective pressure imposed by a phage infection, bacteria may evade phage attachment by altering the structure of this complex glycolipid through mutations in genes involved in LPS biosynthesis [7-9]. As a result, phage-resistant bacterial strains expressing truncated core LPS can emerge. However, mutation to phage resistance is usually accompanied by pleiotropic fitness costs [10,11]. Indeed, it has been reported that "rough" (O-Ag deficient), and "deep rough" (O-Ag deficient, truncated core OS) LPS mutants are less efficient competitors for growth-limiting resources than strains with intact "smooth" LPS [4,12-14]. Although costly in terms of reduced growth rate, such a strategy is often employed by bacteria in response to viral attack during phage treatment. In this regard, while the use of incomplete LPS-specific phages as auxiliary components of phage cocktails has proved beneficial in biocontrol of pathogenic bacteria [15-17], it is surprising that only a very limited number of reports on the isolation and characterization of such viruses have been published thus far.

In this study, we describe incomplete core LPS-specific coliphage vB_EcoM_VpaE1 (subsequently, VpaE1) that has been isolated from its natural habitat. Based on the results presented here, VpaE1 belongs to the newly proposed genus Felix01likevirus, represented by a well-studied Salmonella phage Felix01 $[18,19]$ that infects numerous Salmonella strains and has been often used as a diagnostic and therapeutic agent $[20,21]$. Felix01 has long been considered as a singleton within the family Myoviridae [22]. However, during the last few years, a dozen of its close relatives, active mainly against E. coli [23-27] or Salmonella [28-32] have been isolated and sequenced. In addition, more distant Felix01 relatives that infect Erwinia [33], Citrobacter [34] or Pseudomonas [35] have been described. All Felix01-related Salmonella or Escherichia coli (E. coli) phages were isolated on strains with smooth LPS.

Bacteriophage VpaE1 described in this study differs from other characterized Felix01-like viruses by its specificity towards deep rough strains of E. coli. By using core LPS mutant strains of E. coli K-12 [36], we show that VpaE1 can even use LPS that is truncated down to the inner core OS. Moreover, we demonstrate that VpaE1 can replicate in a wide temperature range from 9 to $49^{\circ} \mathrm{C}$, suggesting that this phage is well adapted to harsh environmental conditions. As a coliphage with unique physiological characteristics, VpaE1 is an attractive model for studying virus-host co-evolution as well as investigating carbohydrate-protein interactions, a research area that has attracted considerable attention in recent years [37]. In addition, to combat the emergence of smooth/rough LPS-specific phage-resistant pathogenic E. coli strains, VpaE1 may be used in phage cocktails.

\section{Materials and Methods}

\subsection{Bacterial Strains and Culture Conditions}

Bacterial strains used for host range analysis and phage propagation are listed in Tables 1 and 2 respectively. Bacteria were cultivated in LB medium, in the temperature range of $7-49^{\circ} \mathrm{C}$. When needed, LB medium was supplemented with either $25 \mu \mathrm{g} \cdot \mathrm{mL}^{-1}$ kanamycin (Kan, Sigma-Aldrich, St. Louis, MO, USA) or $12.5 \mathrm{mg} \cdot \mathrm{mL}^{-1}$ tetracycline (Tet, Sigma-Aldrich).

\subsection{Phage Techniques}

Bacteriophage VpaE1 was isolated from avian feces collected at a farm (Vievis, Lithuania) in 2008. Initially, samples were soaked in PB buffer $\left(70 \mathrm{mM} \mathrm{NaCl}, 10 \mathrm{mM} \mathrm{MgSO}_{4}, 50 \mathrm{mM} \mathrm{Na}_{2} \mathrm{HPO}_{4}\right.$, 
$\left.30 \mathrm{mM} \mathrm{KH} \mathrm{PO}_{4}\right)$ and centrifuged at $4000 \times g$ for $20 \mathrm{~min}$ before filtering through $0.45 \mu \mathrm{m}$ pore-size filters (Sartorius, Goettingen, Germany). Decimal dilutions of the sample were then added to the liquid cultures of E. coli, mixed with $2.5 \mathrm{~mL}$ of $0.5 \%(w / v)$ soft agar and poured over the $1.2 \% \mathrm{LB}$ agar plates that were incubated at $37{ }^{\circ} \mathrm{C}$ overnight. Then, phage suspensions in LB medium were prepared from single plaques. Decimal dilutions of suspensions were plated on the lawns of $E$. coli $\mathrm{B}$ derivatives and incubated in the temperature range of 7 to $49^{\circ} \mathrm{C}$. Thus, phage VpaE1 was selected for further analysis based on its plaque morphology (uniform clear plaques on the lawns of $E$. coli $B$ strains) and a wide temperature range.

Bacteriophage VpaE1 was propagated from a single plaque suspension that was added to the exponentially growing liquid culture of E. coli BL21. Then, the culture was incubated at $37{ }^{\circ} \mathrm{C}$ with vigorous shaking until complete lysis $(\sim 2 \mathrm{~h})$. Phage particles were collected from the lysate by centrifugation at $16,000 \times g$ for $1 \mathrm{~h}$ at $8{ }^{\circ} \mathrm{C}$. The resulting pellet was soaked in $1 \mathrm{~mL}$ of SM buffer $\left(100 \mathrm{mM} \mathrm{NaCl}, 8 \mathrm{mM} \mathrm{MgSO}_{4}, 50 \mathrm{mM}\right.$ Tris-HCl, $\left.\mathrm{pH} 7.5\right)$ containing $0.1 \mathrm{~mL} \mathrm{CHCl}_{3}$ and DNase I ( 2 units per $\mathrm{mL}$; Thermo Fisher Scientific, Vilnius, Lithuania) at $4{ }^{\circ} \mathrm{C}$ overnight. Next day, the bacterial debris was removed by centrifugation at $5000 \times g$ for $10 \mathrm{~min}$ at room temperature. The supernatant was then subjected to $\mathrm{CsCl}$ density gradient centrifugation. The band with the highest opalescence was collected and dialyzed against SM buffer. Purified phage particles were used for TEM, host-range analyses and DNA isolation. Phage stock solution was stored at $4{ }^{\circ} \mathrm{C}$.

The best temperature for VpaE1 propagation was determined by assessing plaque morphology on the lawns of E. coli BL21, after the plates were incubated in the temperature range from $9{ }^{\circ} \mathrm{C}$ to $49^{\circ} \mathrm{C}$.

\subsection{Transmission Electron Microscopy (TEM)}

Phage suspension was diluted to approximately $10^{11} \mathrm{PFU} / \mathrm{mL}$ with distilled water; $5 \mu \mathrm{L}$ of the sample was deposited directly on the carbon-coated nitrocellulose grid. Excess liquid was drained with filter paper before staining with two successive drops of $2 \%$ uranyl acetate $(\mathrm{pH} 4.5)$, dried and examined in Morgagni 268(D) transmission electron microscope (Field Electron and Ion Co., Hillsboro, OR, USA). VpaE1 virions were measured (30 virions in total) after calibration with catalase crystals and/or T4 phage particles.

\subsection{Host Range Analysis}

The host range of VpaE1 was investigated using both spot test assay and determination of the efficiency of plating (EOP) as described by Kutter [38].

\subsection{Adsorption Assays}

\subsubsection{Assay of Adsorbtion Kinetics}

VpaE1 adsorption tests were carried out using E. coli BL21 (reference host), E. coli BW25113 (VpaE1-resistant negative control), and VpaE1-susceptible mutants of E. coli BW25113 from Keio collection [36]. The assay was carried out in triplicate, as described by Kropinski et al. [39] with minor modifications. The mid-log-phase cultures of the aforementioned E. coli strains $\left(\mathrm{OD}_{600}\right.$ of 0.5$)$ were mixed with phage suspension to give a MOI (multiplicity of infection) of 0.1 and incubated at $37^{\circ} \mathrm{C}$. Samples $(0.1 \mathrm{~mL})$ were taken at different time intervals during the time period of $15 \mathrm{~min}$. and diluted with LB medium. Phage-cell complexes were removed by treatment with chloroform (1/10 volume) and centrifugation at $5000 \times g$ for $5 \mathrm{~min}$. The titer of the unadsorbed phage in the supernatant was then determined by the double-layer agar method.

\subsubsection{Periodate and Proteinase K Treatments}

To clarify whether the receptor for VpaE1 is a protein or a carbohydrate, VpaE1 adsorption to the proteinase K- or periodate-treated E. coli cells was tested by phage pull-down assay essentially as described by Kiljunen et al. [40]. For this, cultures of E. coli BL21 and BW25113, as well as BW25113 
mutants $\Delta$ waag and $\Delta$ waap were grown in LB medium at $37^{\circ} \mathrm{C}$ with vigorous shaking until mid-log $\left(\mathrm{OD}_{600}\right.$ of 0.5$)$. For proteinase K (Thermo Fisher Scientific) treatment, $2 \mathrm{~mL}$ of each culture was collected by centrifugation at $14,000 \times g$ for $1 \mathrm{~min}$ and the pellet was suspended in $2 \mathrm{~mL}$ of LB medium. The bacterial suspension was divided into two equal parts: one of these was incubated at $37^{\circ} \mathrm{C}$ for $2 \mathrm{~h}$ (control sample), while the other was treated with Proteinase $\mathrm{K}(0.2 \mathrm{mg} / \mathrm{mL})$ at $37^{\circ} \mathrm{C}$ for $2 \mathrm{~h}$.

For the periodate treatment, $2 \mathrm{~mL}$ of each culture was harvested by centrifugation, as described above. The pellet was then suspended in $1 \mathrm{~mL}$ of sodium acetate $(50 \mathrm{mM}$, adjusted to $\mathrm{pH}$ 5.2) or $1 \mathrm{~mL}$ sodium acetate containing $100 \mathrm{mM}$ of $\mathrm{NaIO}_{4}$ (BDH Chemicals Ltd, Poole, England) and incubated at $37^{\circ} \mathrm{C}$ for $2 \mathrm{~h}$ in the dark.

Treated cells were washed three times with $1 \mathrm{~mL}$ of LB medium. After the final wash, the cells were suspended in $1 \mathrm{~mL}$ of LB medium. Then, the $\mathrm{A}_{600}$ of the bacterial suspension was adjusted to $\sim 0.5$, and the phage adsorption assay was carried out. Phage adsorption was assessed by pull-down assay, where centrifugation removes phage particles bound to the bacterial cells. For this, treated bacterial suspensions were incubated with $\mathrm{VpaE} 1(\mathrm{MOI}=0.1)$ for $10 \mathrm{~min}$ at $37^{\circ} \mathrm{C}$, then cell-phage complexes were removed by centrifugation for $5 \mathrm{~min}$ at $5000 \times g$, and the number of unadsorbed phage particles remaining in the supernatant was determined in triplicate by the double-layer agar method using E. coli BL21. The adsorption ratio was calculated from comparison to a negative control in LB medium without cells.

\subsection{Phage DNA Isolation and Analysis}

Aliquots of phage suspension $\left(10^{11}-10^{12} \mathrm{PFU} / \mathrm{mL}\right)$ were subjected to phenol/chloroform extraction and ethanol precipitation. Isolated phage DNA was subsequently used for restriction analysis, or was subjected to genome sequencing. Restriction digestion was performed with Bsu15I, XbaI, HhaI, Csp6I, EcoRV, and CfrI restriction endonucleases (Thermo Fisher Scientific) according to the supplier's recommendations. DNA fragments were separated by electrophoresis in a $0.8 \%$ agarose gel containing ethidium bromide. Restriction analysis was performed in triplicate to confirm the results.

\subsection{Genome Sequencing, Assembly and Annotation}

The complete genome sequence of VpaE1 was determined using Illumina DNA sequencing technology at BaseClear, the Netherlands. Open reading frames (ORFs) were predicted with Glimmer v2.02 [41] and Geneious v5.5.6. [42]. Analysis of the genome sequence was performed using the Fasta-Protein, Fasta-Nucleotide, Fasta-Genome, BLAST2, PSI-Search, Transeq, ClustalW2, (European Bioinformatics Institute, Hinxton, UK), programs, and tRNAscan-SE 1.21 [43] was used to search for tRNAs. The complete genome sequence of $\mathrm{vB} \_$EcoM_VpaE1 was deposited in the EMBL nucleotide sequence database under accession number KM657822.

\subsection{Phylogenetic Analysis}

Phylogenetic and molecular evolutionary analyses were conducted using MEGA version 5 [44]. The neighbor-joining tree based on the whole-genome sequence alignment was constructed using Geneious v5.5.6 [42], Genome sequences used for alignment can be found at NCBI: Felix_01 (AF320576); Mushroom (KP143762); FO1a (JF461087); vB_EcoM_AYO145A (KR014248); UAB_Phi87 (JN225449); HY02 (KM092515); O157_phage_12 (KP869110); O157_phage_11 (KP869109); WV8 (EU877232); EC6 (JX560968); JH2 (KF055347); HB-2014 (KP010413); O157_phage_1 (KP869100); phiEa21-4 (FQ482083); and Michonne (KT001916). 


\subsection{Analysis of VpaE1 Virion Structural Proteins}

\subsubsection{SDS-PAGE}

CsCl-purified phage particles $\left(\sim 10^{10}\right)$ resuspended in a buffer containing $60 \mathrm{mM}$ Tris- $\mathrm{HCl}$ $(\mathrm{pH} 6.8), 1 \%$ SDS $(w / v), 1 \%$ 2-mercaptoethanol $(v / v), 10 \%$ glycerol $(v / v)$ and $0.01 \%$ bromophenol blue $(w / v)$ were boiled for 3 min and separated on 12\% SDS PAGE following the method described by Laemmli [45]. Protein bands were visualized by staining with PageBlue Protein Staining Solution (Thermo Fisher Scientific).

\subsubsection{Filter-Aided Protein Sample Preparation (FASP) for Mass Spectrometry Analysis}

CsCl-purified phage particles were concentrated on Amicon Ultra-0.5 mL $30 \mathrm{kDa}$ centrifugal filter unit and were denatured in $8 \mathrm{M}$ urea, $100 \mathrm{mM}$ DTT solution with continuous rotation at $800 \mathrm{rpm}$ in the temperature controlled shaker for 3 hours at $37^{\circ} \mathrm{C}$. Trypsin digestion was performed according to a modified FASP protocol $[46,47]$. Briefly, phage particles were washed with buffer containing $8 \mathrm{M}$ urea. The proteins were alkylated using iodoacetamide. Buffer was exchanged by washing twice with $50 \mathrm{mM} \mathrm{NH} \mathrm{HCO}_{3}$, and proteins digested overnight with TPCK Trypsin 20233 (Thermo Scientific, Rockford, IL, USA). Then the peptides were recovered by centrifugation and washed twice with 50\% $\mathrm{CH}_{3} \mathrm{CN}$. Afterwards, the samples were combined, acidified, lyophilized, redissolved in $0.1 \%$ formic acid and analyzed by mass spectrometry.

\subsubsection{Liquid Chromatography and Mass Spectrometry}

Liquid chromatography (LC) separation of trypsin cleaved peptides was performed with a nanoAcquity UPLC system (Waters Corporation, Wilmslow, UK). Peptides were loaded on a reversed-phase trap column PST C18, 100A $5 \mu \mathrm{m}, 180 \mu \mathrm{m} \times 20 \mathrm{~mm}$ (Waters Corporation) at a flow-rate of $15 \mu \mathrm{L} / \mathrm{min}$ using loading buffer of $0.1 \%$ formic acid and subsequently separated on HSS-T3 C18 $1.8 \mu \mathrm{m}, 75 \mu \mathrm{m} \times 250 \mathrm{~mm}$ analytical column (Waters Corporation) in $60 \mathrm{~min}$ linear gradient (A: $0.1 \%$ formic acid, $\mathrm{B}: 100 \% \mathrm{CH}_{3} \mathrm{CN}$ and $0.1 \%$ formic acid) at a flow rate of $300 \mathrm{~nL}$ per min. The analytical column temperature was kept at $40{ }^{\circ} \mathrm{C}$.

The nano-LC was coupled online through a nanoESI $7 \mathrm{~cm}$ length, $10 \mathrm{~mm}$ tip emitter (New Objective, Woburn, MA, USA) with HDMS Synapt G2 mass spectrometer (Waters Corporation). Data were acquired using Masslynx version 4.1 software (Waters Corporation) in positive ion mode. LC-MS data were collected using data independent acquisition (DIA) mode in combination with online ion mobility separations. The trap and transfer collision energy for high-energy scans in HDMS mode was ramped from 4 to $5 \mathrm{eV}$ and from 27 to $50 \mathrm{eV}$. For both analyses, the mass range was set to 50-2000 Da with a scan time set to $0.9 \mathrm{~s}$. A reference compound [Glu1]-Fibrinopeptide B (Waters Corporation) was infused continuously $(500 \mathrm{fmol} / \mu \mathrm{L}$ at flow rate $500 \mathrm{~nL}$ per $\mathrm{min}$ ) and scanned every $30 \mathrm{~s}$ for online mass spectrometer calibration purposes.

\subsubsection{Data Processing, Search and Analysis}

Raw data files were processed and searched using ProteinLynx Global SERVER (PLGS) version 2.5.3 (Waters Corporation). The following parameters were used to generate peak lists: (i) minimum intensity for precursors was set to 150 counts; (ii) minimum intensity for fragment ions was set to 50 counts; (iii) intensity was set to 500 counts. Processed data was analyzed using trypsin as the cleavage protease, one missed cleavage was allowed and fixed modification was set to carbamidomethylation of cysteines, variable modification was set to oxidation of methionine. Minimum identification criteria included 1 fragment ion per peptide, 3 fragment ions per protein and minimum of 2 peptides per protein. The false discovery rate (FDR) for peptide and protein identification was determined based on the search of a reversed database, which was generated automatically using PLGS when global false discovery rate was set to $4 \%$. The database comprising 
all possible VpaE1 ORFs (>50 codons) was generated using Geneious v5.5.6 [42], and was used for the identification of VpaE1 structural proteins.

\section{Results}

\subsection{Phage Isolation and Analysis of VpaE1 Plaque and Virion Morphology}

Bacteriophage VpaE1 was isolated in Lithuania while screening for phages with distinct physiological properties [48-51]. In the course of this screening, no natural bacterial hosts were collected; therefore E. coli strain BL21 was used as a reference host for the isolation and propagation of VpaE1.

To investigate the effect of temperature on VpaE1 plaque formation, diluted phage suspensions were plated on E. coli BL21, and the plates were incubated at 9,37 and $47{ }^{\circ} \mathrm{C}$. As seen in Figure 1 , at $37^{\circ} \mathrm{C}$ the plaques produced by VpaE1 ( 1.5 mm in diameter) were the most clear and uniform, therefore the subsequent phage propagation and adsorption experiments were carried out at this temperature.

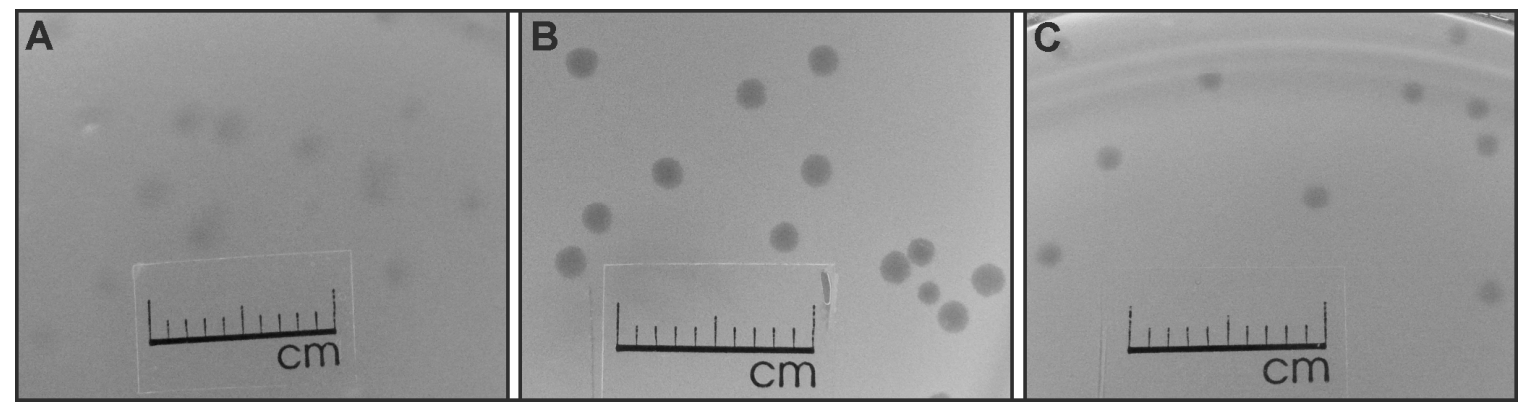

Figure 1. The morphology of VpaE1 plaques produced on the lawns of E. coli BL21 at different temperatures. Plaques are shown after: (A) five days of incubation at $9{ }^{\circ} \mathrm{C}$; (B) $24 \mathrm{~h}$ of incubation at $37^{\circ} \mathrm{C}$; and (C) $24 \mathrm{~h}$ of incubation at $47^{\circ} \mathrm{C}$.

It is worth mentioning that bacteriophage VpaE1 was also capable of multiplying at $49{ }^{\circ} \mathrm{C}$, yet the plaques formed at this temperature were too small to be photographed.

When the content of a single plaque was added to a $10 \mathrm{~mL}$ of the exponentially growing liquid culture in LB medium $\left(\mathrm{OD}_{600}\right.$ of 0.5$)$ lysis occurred within $\sim 2 \mathrm{~h}$. At $37^{\circ} \mathrm{C}$, E. coli BL21 was capable of producing phage titers of $10^{11}-10^{12} \mathrm{pfu} \mathrm{mL}^{-1}$. The morphology of CsCl-purified VpaE1 particles was analyzed using transmission electron microscopy (TEM) (Figure 2).
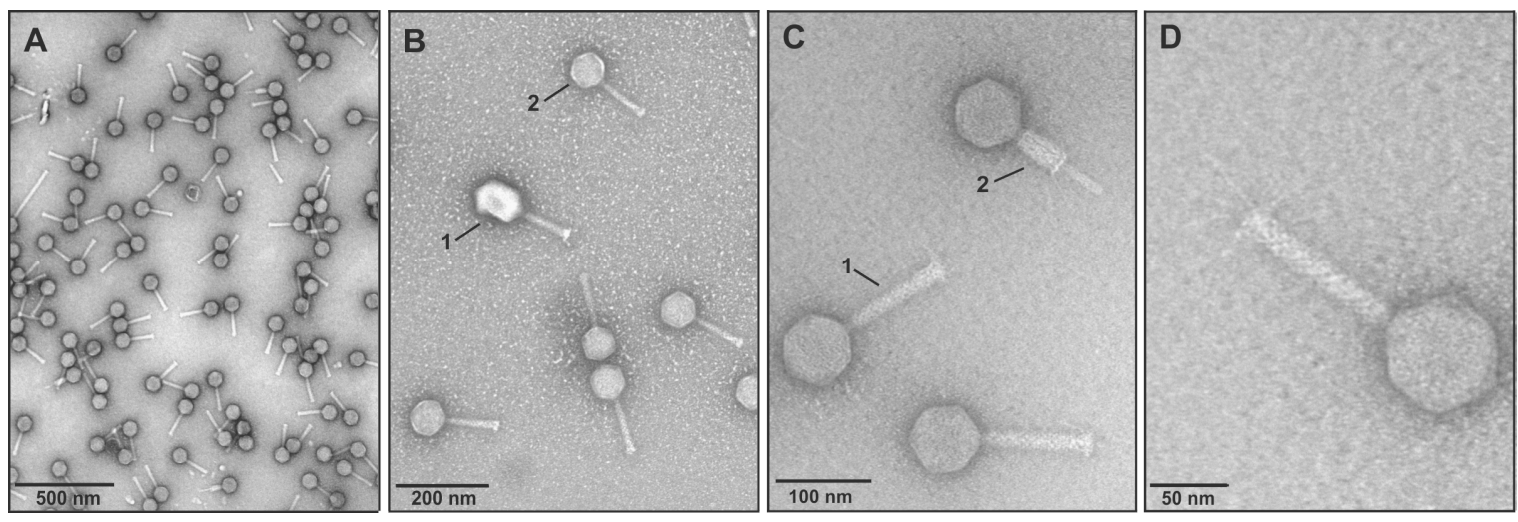

Figure 2. Electron micrographs of bacteriophage VpaE1. (A and B.2) $\mathrm{CsCl}$ density gradient-purified VpaE1 and (B.1) T4 particles; (C) VpaE1 particles with extended (C.1) and contracted (C.2) tail; and (D) close-up view of VpaE1 particle with tail fibers. 
Electron micrographs showed that VpaE1 belongs to the family Myoviridae and is characterized by an isometric head of $77 \mathrm{~nm}$ in apical diameter and a necked contractile tail of 120 by $16 \mathrm{~nm}$ (in the extended form) with long tail fibers connected to the baseplate (Figure 2). In addition, the general appearance of VpaE1 particle is similar to that of other characterized Felix01-like viruses [23,33].

\subsection{The Host Range of VpaE1}

To investigate the host range of VpaE1, a quantitative spot dilution test was employed. As seen in Table 1, those E. coli strains that express O-antigen (STEC group) were completely resistant to VpaE1, as were both Salmonella and Klebsiella strains used in this study. Moreover, the test revealed that E. coli $\mathrm{K}-12$ derivatives were also resistant to VpaE1, and only E. coli B strains were sensitive to the phage tested.

Table 1. Host Range of vB_EcoM_VpaE1.

\begin{tabular}{|c|c|c|}
\hline Strain & Spot Test & Source/Reference \\
\hline \multicolumn{3}{|l|}{ E. coli B strains } \\
\hline $\mathrm{B}^{\mathrm{E}}$ & + & Lindsay W. Black \\
\hline BL21 & + & Novagen \\
\hline BL21(DE3) & + & Novagen \\
\hline B40 & + & Lindsay W. Black \\
\hline BE-BS & + & Kenneth N. Kreuzer/[52] \\
\hline \multicolumn{3}{|l|}{ E. coli $\mathrm{K} 12$ strains } \\
\hline MG1655 & - & Edita Sužiedèlienè \\
\hline K803 & - & Lindsay W. Black \\
\hline XL1blue & - & Stratagene \\
\hline CR63 & - & Kenneth N. Kreuzer/[52] \\
\hline BW25113 & - & [53] \\
\hline \multicolumn{3}{|l|}{ E. coli STEC representatives } \\
\hline O157:H7 & - & Edita Sužiedèlienè \\
\hline O103:H2 & - & Edita Sužiedèlienè \\
\hline O111:H8 & - & Edita Sužiedèlienè \\
\hline $\mathrm{O} 145: \mathrm{H} 28$ & - & Edita Sužiedèlienè \\
\hline O26:H11 & - & Edita Sužiedèlienè \\
\hline \multicolumn{3}{|l|}{ Other enterobacteria } \\
\hline Salmonella Typhimurium LT2 & - & Jaunius Urbonavičius \\
\hline Klebsiella pneumoniae KV-3 & - & {$[54]$} \\
\hline
\end{tabular}

\subsection{Annotation and Overview of VpaE1 Genome}

Since many of the genomes of Felix01-related phages have already been examined in detail and published, herein is provided only a brief overview of VpaE1 genome. Bacteriophage VpaE1 has a linear ds DNA genome of $88,403 \mathrm{bp}$ that is similar in size to those of other Felix01-related viruses whose genome sizes range between 84 and $93 \mathrm{~kb}[19,23,24,27,29,32,33,35]$. As is the case with other virulent phages, the VpaE1 genome has an average mol\% G+C content of $38.9 \%$, which differs significantly from that of the host $(\sim 50 \%)$. According to the literature, the drop in $\mathrm{G}+\mathrm{C}$ content in combination with various forms of DNA modification is known to protect the phage DNA from cleavage by restriction enzymes of the host $[55,56]$.

The restriction digestion analysis in silico revealed that the DNA of VpaE1 has no recognition sites for many common restriction enzymes (such as BamHI, XhoI, SalI, KpnI, SacI, PstI and even MboI, which recognizes GATC), a feature that is usually observed in phages with unmodified DNA. To test for the digestibility of VpaE1 DNA, 6 restriction enzymes with different sensitivity to DNA methylation were used, namely CfrI (affected by Dcm/CpG methylation), Bsu15I (sensitivity to Dam/CpG methylation), XbaI (sensitivity to Dam methylation), HhaI (affected by CG methylation), Eco32I and Csp6I (both not affected by Dcm, CpG or Dam methylation). Since all enzymes 
digested the DNA of VpaE1 (Figure 3), restriction analysis indicated that VpaE1 genome contains no modified nucleotides.

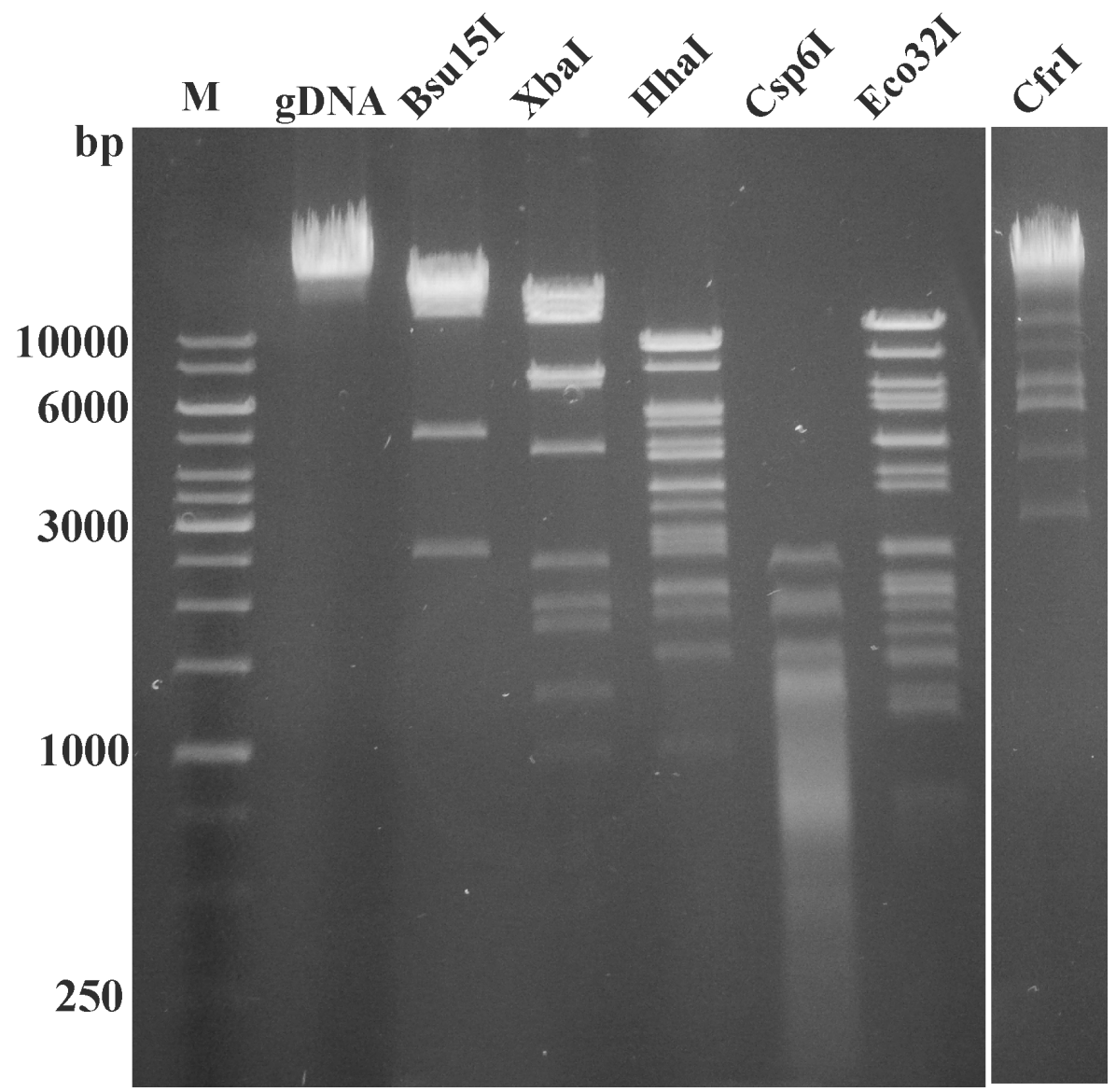

Figure 3. Restriction digestion patterns of phage VpaE1 genomic DNA (gDNA). Lane M represents GeneRuler ${ }^{\mathrm{TM}} 1 \mathrm{~kb}$ DNA Ladder (Thermo Fisher Scientific).

This is further supported by the results from bioinformatics analysis, which revealed that no characterized enzymes implicated in DNA modification have homologues in VpaE1. Bioinformatics analysis indicated that the genome of VpaE1 encodes 132 putative open reading frames (ORFs) and 20 tRNAs (Figure 4).

All VpaE1 ORFs had homologues in other sequenced members of Felix01likevirus (Table S1). As was the case with other members of Felix01likevirus, nearly 70\% of VpaE1 ORFs encoded hypothetical proteins with no known functions. Thus, through the examination of homology search results, a putative function could be assigned to only 38 VpaE1 ORFs (Figure 4). In addition, MS/MS analysis allowed for the identification of 11 virion proteins, which were encoded by VpaE1 ORFs with homology to various hypothetical proteins only. 


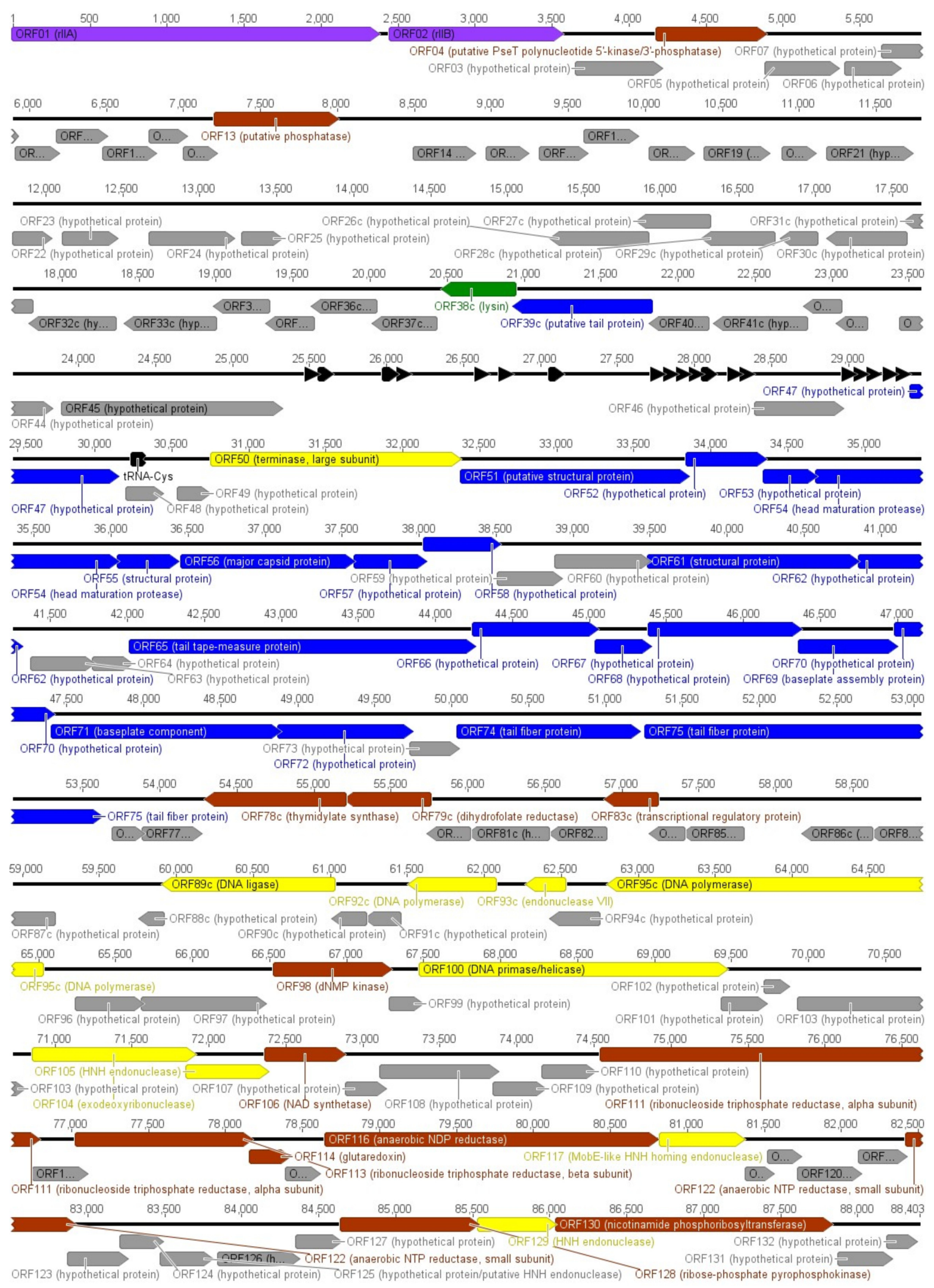

Figure 4. Functional genome map of phage VpaE1. Functions are assigned according to the characterized ORFs in NCBI database and/or MS/MS analysis. The color code is as follows: yellow-DNA replication, recombination, repair and packaging; brown-transcription, translation, nucleotide metabolism; blue—structural proteins; green-lysis; purple—phage-host interaction; and grey-ORFs of unknown function black-tRNA. 


\subsection{Structural Proteins and Virion Proteome}

In-gel and in-solution digestion are two common methods used for the analysis of phage structural proteins $[57,58]$. However, to identify the structural proteins of VpaE1, a recently improved filter-aided sample preparation (FASP) method [46,47] was used. Since following this procedure, most of the contaminants and detergents are being effectively removed from the biological samples. Prior to LC-MS/MS, a quality of phage suspension was verified by SDS PAGE (Figure 5A). Then, reversed-phase nano-liquid chromatography directly coupled with LC-MS/MS analysis was performed that allowed experimental identification of 22 structural proteins of VpaE1 (Figure 5B), including 11 that had no reliable homologues to annotated structural proteins in other organisms.

A

\section{B}

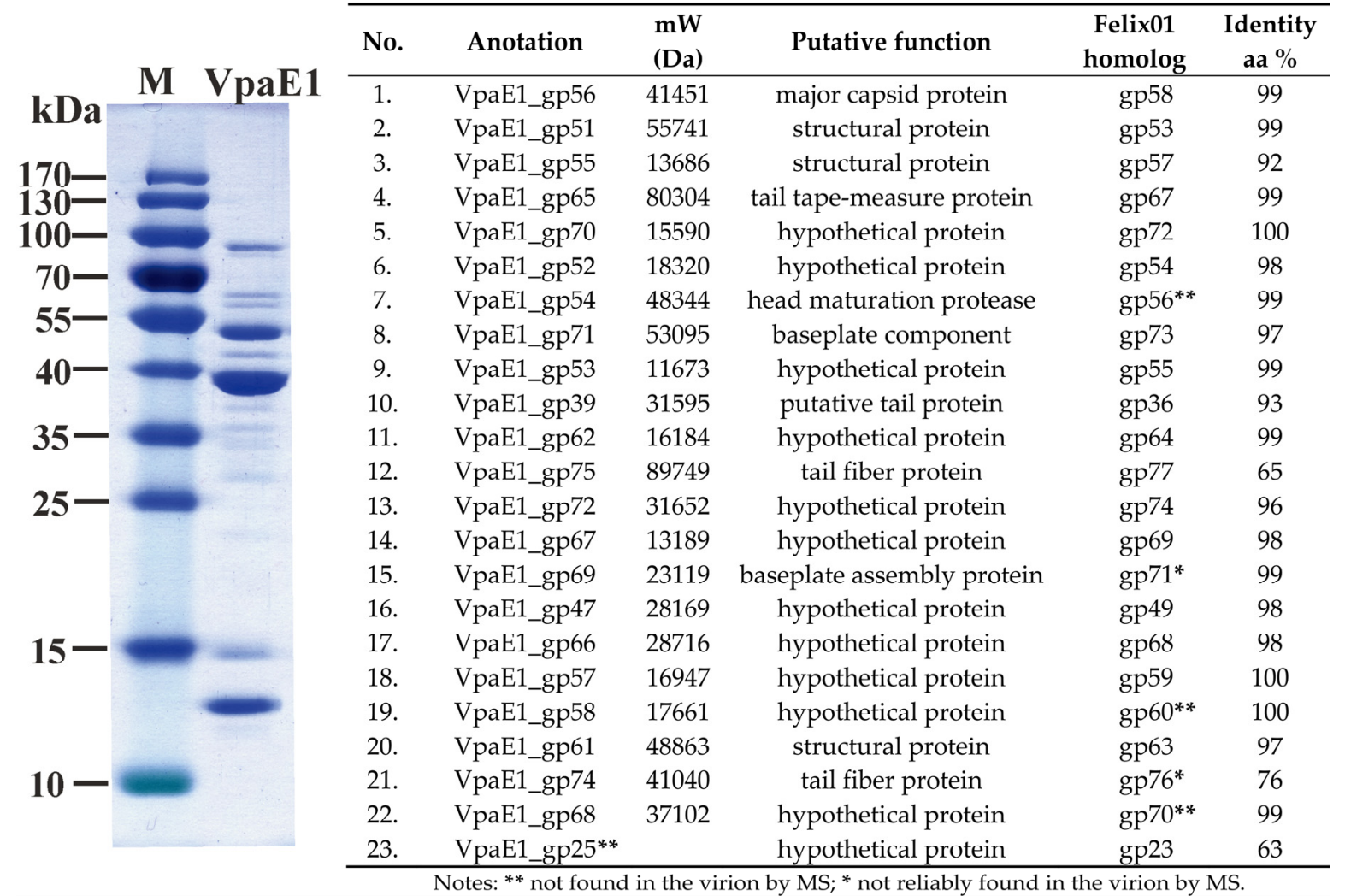

Figure 5. Analysis of protein composition of VpaE1 virion: (A) SDS-PAGE analysis of phage VpaE1 particles; and (B) the list of VpaE1 structural proteins identified by MS in comparison with those in the virion of Felix01 identified previously [19].

All identified structural proteins of VpaE1, except the putative tail fiber protein VpaE1_gp75, shared high sequence similarities with their corresponding counterparts in Felix01. Unexpectedly, MS/MS failed to detect a homologue of Felix01_gp23 among the virion proteins of VpaE1. In contrast, three proteins that were detected in VpaE1 (namely, VpaE1_gp54, VpaE1_gp58 and VpaE1_gp68) had not been identified within the particle of Felix01 [19].

\subsection{Phylogenetic Relatedness}

To assess the evolutionary relationships between VpaE1 and other Felix01-related phages, a comparative whole genome sequence analysis was performed. For this, complete genome sequences of 14 Felix01-like viruses that infect E. coli or Salmonella strains as well as those of Erwinia phage phiEa21-4 and Citrobacter phage Michonne were aligned with the genome of VpaE1. As seen in 
Figure 6, the phylogenetic analysis revealed that Felix01-like viruses form five separate but closely related groups.

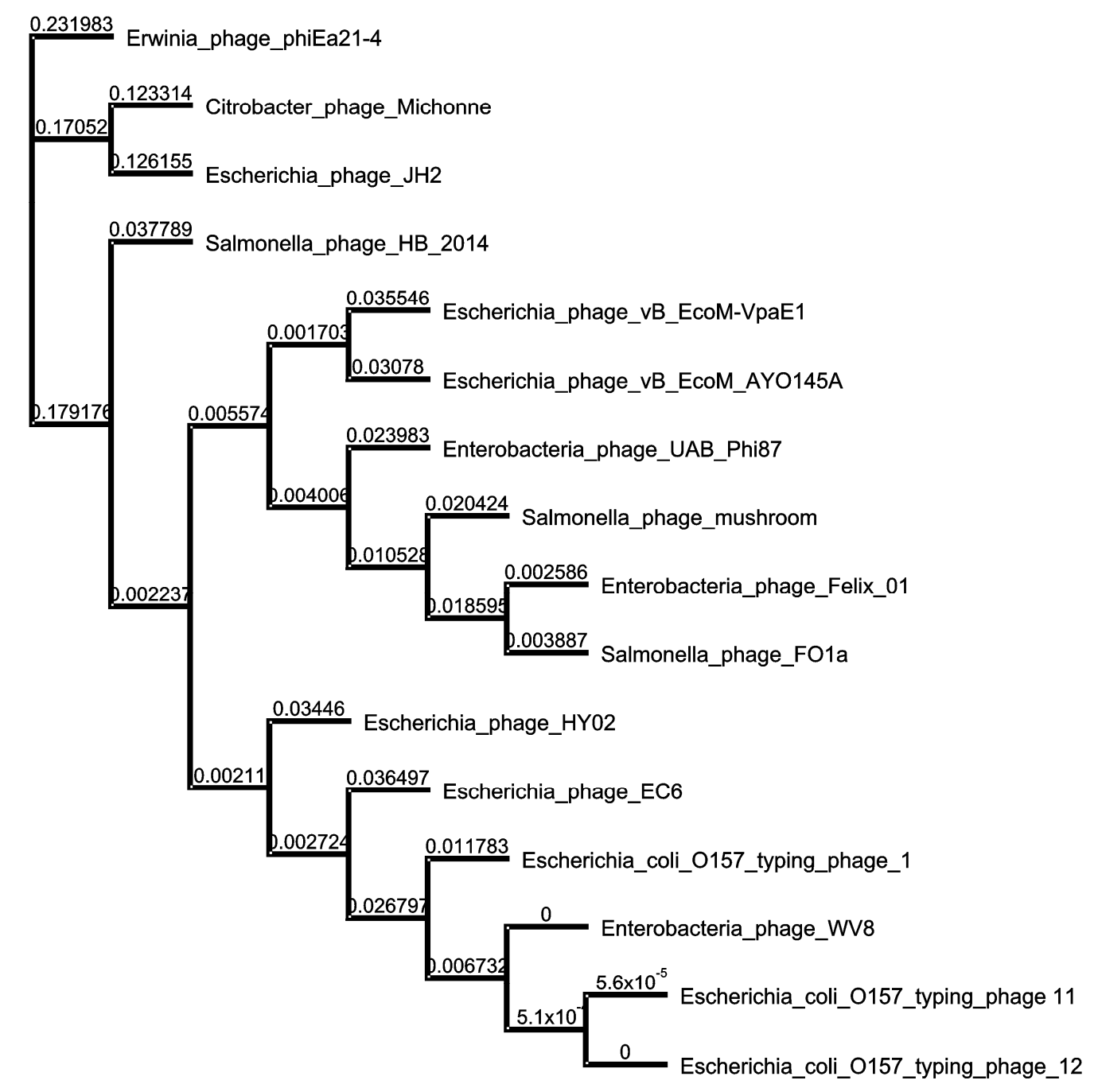

Figure 6. Neighbor-joining tree based on the whole-genome sequence alignment. The numbers at the nodes indicate the bootstrap probabilities.

Overall, the branching order of groups is somewhat consistent with the defined host range phenotypes seen in Felix01likevirus. One such group comprises six E. coli O157:H7-infecting phages (namely, WV8, EC6, HY02, ECTP1, ECTP11 and ECTP 12), suggesting that these viruses are likely adapted to avoid specific restriction-modification systems that vary considerably between different lineages of E. coli [59-61]. Bacteriophage JH2, which is the only Felix01-like virus capable of infecting E. coli ETEC (enterotoxigenic) serotype O8:H9 [25], together with Citrobacter phage Michonne forms a separate divergent branch on the tree. Bacteriophage VpaE1, which is most closely related to E. coli O145-serotype-specific phage vB_EcoM_AYO145A isolated in Canada [27], occupies a separate branch together with 5 other Felix01-like viruses that infect Salmonella or Escherichia.

\subsection{Identification of VpaE1 Receptor}

The results presented in Table 1 suggest that the ability of VpaE1 to adsorb to the host cell is likely influenced by the LPS structure. To confirm this, bacteriophage VpaE1 was tested against a set of E. coli K-12 strains that are mutant in the biosynthesis pathway of LPS [36]. Initially, a spotting assay was employed (Table 2). 
Then, when the clearly modified infections were observed, determination of the efficiency of plating (EOP) was performed using E. coli K-12 BW25113 and other VpaE1-resistant strains from the Keio collection as a negative control (Figure 7A). In the course of this experiment, the ability of VpaE1 to infect different $E$. coli $\mathrm{B}$ derivatives was also examined.

Table 2. Susceptibility of E. coli BW25113 Mutant Strains to VpaE1.

\begin{tabular}{ccc}
\hline E. coli K-12 BW25113 Mutants & Spot Test & Source/Reference \\
\hline$\Delta$ waaC & - & Keio collection $/[36]$ \\
$\Delta$ waaF & - & Keio collection $/[36]$ \\
$\Delta$ waaG & + & Keio collection/[36] \\
$\Delta$ waaP & + & Keio collection $/[36]$ \\
$\Delta$ waaY & - & Keio collection $/[36]$ \\
$\Delta$ waaQ & - & Keio collection $/[36]$ \\
$\Delta$ waaO & - & Keio collection $/[36]$ \\
$\Delta$ waaR & + & Keio collection $/[36]$ \\
$\Delta$ waaB & \pm & Keio collection $/[36]$ \\
$\Delta$ waaZ & \pm & Keio collection/[36] \\
\hline
\end{tabular}

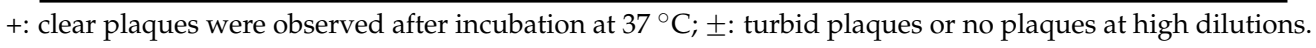

A

\begin{tabular}{|c|c|c|}
\hline Strain & Predicted LPS Composition & EOP \\
\hline E. coli BL21 & Inner core OS + GlcI + GlcII & 1.00 \\
\hline BL21(DE3) & Inner core OS + GlcI + GlcII & $1.19 \pm 0.05$ \\
\hline B40 & Inner core OS + GlcI + GlcII & $1.05 \pm 0.02$ \\
\hline BE-BS & Inner core OS + GlcI + GlcII & $0.41 \pm 0.05$ \\
\hline $\mathrm{B}^{\mathrm{E}}$ & Inner core OS + GlcI + GlcII & $0.98 \pm 0.03$ \\
\hline E. coli K-12 BW25113 & Intact core OS & - \\
\hline \multicolumn{3}{|c|}{ E. coli $\mathrm{K}-12$ BW25113 mutants: } \\
\hline$\Delta w a a C$ & Hep-deficient & - \\
\hline$\Delta w a a F$ & Kdo + HepI & - \\
\hline$\Delta w u n G$ & Inner core OS, HepI lacks P & $1.64 \pm 0.01$ \\
\hline$\Delta w a a P$ & Intact core OS, HepIII-deficient, HepI and HepII lacks P & $1.43 \pm 0.04$ \\
\hline$\Delta w a a Y$ & Intact core OS, HepII lacks $P$ & - \\
\hline$\Delta w a a Q$ & Intact core OS, HepIII-deficient, HepII lacks P & - \\
\hline$\Delta w a a O$ & Inner core OS + GlcI & - \\
\hline$\Delta w a a R$ & Inner core OS + GlcI + GlcII & $1.30 \pm 0.02^{*}$ \\
\hline$\Delta w a a B$ & Intact core OS, Gal-deficient & $0.36 \pm 0.03^{* *}$ \\
\hline$\Delta$ waaZ & Intact core OS, KdoIII-deficient & $0.51 \pm 0.15^{* *}$ \\
\hline
\end{tabular}

Notes: * small plaques; ${ }^{* *}$ very small plaques.

B

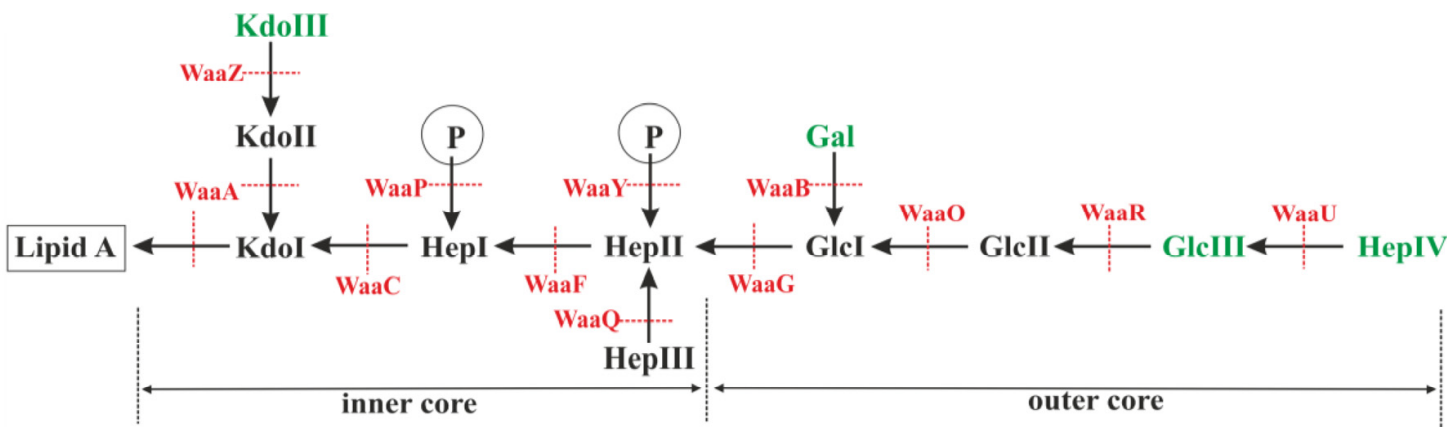

Figure 7. Plating efficiency of VpaE1 on different E. coli strains at $37{ }^{\circ} \mathrm{C}(\mathbf{A})$; and schematic representation of the LPS structure of E. coli K-12 (B), adapted based on the data from [4,12,13,62-66]. Residues shown in black are shared between E. coli K-12 and E. coli B LPS. 
As seen in Figure 7, in the case of E. coli K-12 BW25113 $\Delta w a a G$, a significantly higher EOP of VpaE1 was observed than on the lawns of the reference host BL21. The same effect was seen when E. coli K-12 BW25113 $\Delta$ waaR was used, although the plaques formed by VpaE1 on this particular strain were relatively smaller than those on BL21. Therefore, when LPS was truncated even down to the inner core OS, bacteriophage VpaE1 showed higher infectivity towards mutant $E$. coli K-12 strains rather than B derivatives. In addition, the increase in the EOP was also observed when VpaE1 was grown on E. coli K-12 $\Delta$ waaP, a mutant strain with an impaired inner core region (unphosphorylated core, no HepIII added) [12]. Notably, VpaE1 could also infect E. coli $\mathrm{K} \Delta$ waaB and $\Delta$ waaZ (lack Gal and KdoIII residues, respectively), while both $\Delta w a a F$ and $\Delta w a a C$ (the inner core OS truncated down to KdoI and KdoI-HepI, respectively) mutants were resistant to VpaE1 infection. These results suggest that the core residues of the inner core OS are important for VpaE1 adsorption. Unexpectedly, E. coli B strains differed in their susceptibility to VpaE1 as well. As seen in Figure 7, the EOP of VpaE1 on E. coli BE-BS was reduced more than two-fold, as compared to its EOP on other E. coli B-derivatives. However, this puzzling phenomenon needs to be investigated in more depth and is left for future research.

At first glance, it seems that VpaE1 adsorb better when HepI lacks a P moiety, however, our results show that E. coli K-12 BW25113 mutants $\Delta w a a R, \Delta w a a B$ and $\Delta w a a Z$ as well as E. coli B strains-that all possess phosphorylated HepI-are all susceptible to VpaE1. Therefore, the additional studies are needed to elucidate the precise mechanism of VpaE1 host-cell recognition.

To confirm that VpaE1 failed to form plaques on E. coli BW25113 due to its inability to adsorb to K-12-type LPS, the adsorption assay was performed using several phage-resistant and phage-susceptible strains. The results presented in Figure 8A indicated that bacteriophage VpaE1 indeed failed to adsorb to E. coli K-12 BW25113, whereas in the case of E. coli BL21, BW25113 $\Delta$ waaG and $\Delta$ waa $P$ the adsorption of the phage was unaffected.

A
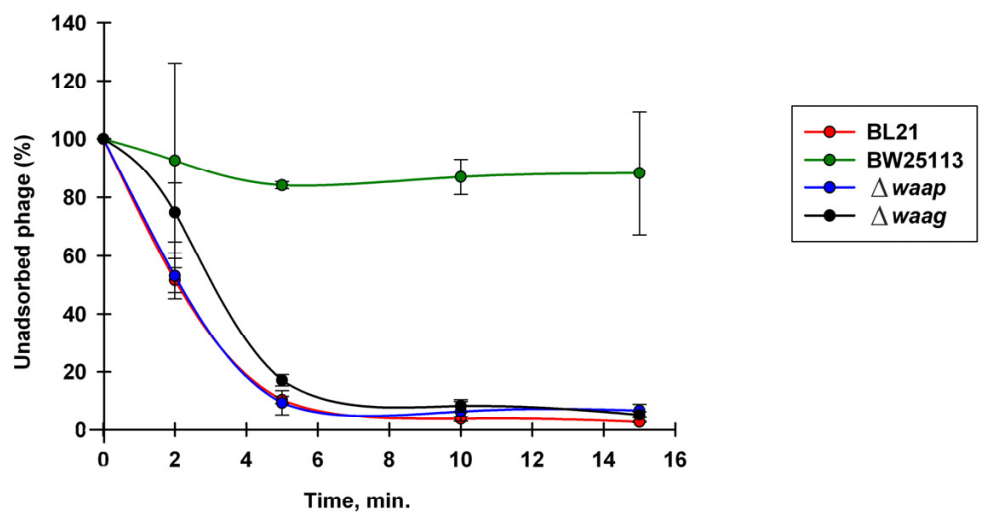

B
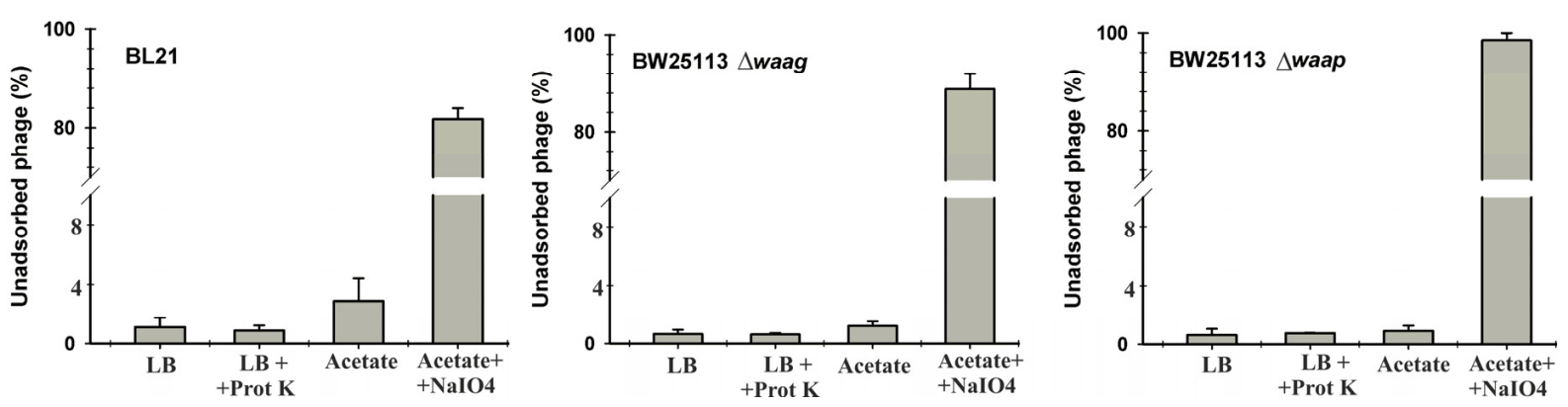

Figure 8. VpaE1 adsorption assays: (A) VpaE1 adsorption kinetics; and (B) effect of proteinase K, sodium acetate and periodate treatment on the ability of VpaE1 to adsorb to E. coli BL21, BW25113 $\Delta w a a G$ and $\Delta w a a P$. 
To test whether the receptor for VpaE1 is a carbohydrate but not a protein, bacteria were treated with proteinase $\mathrm{K}$ or periodate prior to the phage adsorption assay (Figure $8 \mathrm{~B}$ ). Sodium periodate degrades carbohydrates, whereas proteinase $\mathrm{K}$ that has a broad substrate specificity degrades cell surface proteins. As seen in Figure 8, the proteinase K treatment had no effect on VpaE1 adsorption, whereas the incubation of $E$. coli cells in the presence of $100 \mathrm{mM}$ periodate reduced VpaE1 adsorption by $\sim 80 \%$. These results indicate that a receptor for bacteriophage $\mathrm{VpaE} 1$ is carbohydrate of incomplete core LPS.

\section{Discussion}

Here we present bacteriophage VpaE1 whose virion morphology as well as genome characteristics are reminiscent of those found in the members of the newly proposed genus Felix01likevirus, which comprises 14 fully sequenced Salmonella and E. coli phages. The genomes of Felix01-related phages exhibit a high degree of homology, and VpaE1 is no exception. Genome alignment comparison has shown remarkable similarity (in most cases, $>84 \%$ nucleotide sequence identity) between the genome of VpaE1 and other sequenced Felix01-like viruses. Moreover, almost all functionally assigned VpaE1 genes, except for gene 75 coding putative tail fiber protein, share $>90 \%$ amino acid sequence identity with those from the genomes of other Felix01-like viruses, suggesting that the core genome of Felix01likevirus is highly conserved. As is the case with Felix01 and its relatives, bacteriophage VpaE1 contains numerous genes involved in DNA replication and metabolism suggesting that Felix01-related viruses, like many other lytic phages, direct their own replication machinery. Also, the genome of VpaE1 codes for 22 apparently functional tRNAs (a feature that has been also documented in other Felix01-like viruses) that may have a positive impact on translation of phage-derived mRNA. Bacteriophage VpaE1 and its relatives do not code for their own RNA polymerase, nor do they code for proteins required for modification of the host RNAP. Hence, in the case of Felix01-like viruses, the question on how transcription is temporally regulated (especially at early stages of infection) remains unanswered.

Despite the aforementioned similarities, bacteriophage VpaE1 profoundly differs from the rest of Felix01-like viruses, since it is the only coliphage among Felix01likevirus that does not infect smooth LPS bacteria. All Felix 01-like Salmonella and E. coli phages characterized thus far have been isolated based on their ability to target a specific serotype of bacteria, and to date, no Felix01-related bacteriophages have been reported to infect O-Ag-deficient strains, much less O-Ag-deficient strains with a truncated core LPS. This could be at least partially due to the fact that such phages seem to be relatively rare in nature, since their rough or deep rough hosts, which usually emerge as a result of the selective pressure imposed by O-Ag/smooth LPS-specific phage infection [3], have been found to be not fit enough to survive the competition for natural resources with smooth strains, and are usually more susceptible to abiotic stress [11-13,62]. However short-lived, bacterial populations that produce mutant LPS occasionally do emerge in nature, and so do, apparently, mutant LPS-specific bacteriophages.

In the case of many tailed viruses, the distal part of the phage tail fibers is responsible for host cell recognition. As seen in Figure 5, bacteriophage VpaE1 harbors two putative tail fiber proteins, namely VpaE1_gp74 and VpaE1_gp75. Based on BLASTP analysis, both the C-terminus of VpaE1_gp75 (aa 584-780) and the C-terminal region of VpaE1_gp74 (aa 146-362) show homology to the long tail fiber adhesin of $\mathrm{T} 4$ (54\% identity/E-value $2 \mathrm{e}-51$ and $37 \%$ identity/E-value 9e-32, respectively). In T4, the long tail fiber adhesin is located in the C-terminal domain of gp37, and recognizes E. coli B LPS with at least one of the two terminal glucose (Glc) residues present [67] and OmpC found on E. coli $\mathrm{K}-12$ but not B derivatives [68]. On the contrary, the host range of VpaE1 is limited to E. coli B strains only, since this phage does not use K-12-type LPS as a receptor. Although strikingly similar in genome size and gene content, E. coli B and K-12 derivatives mostly differ in the copy number and distribution of IS elements $[65,69]$ that account for the majority of phenotypic differences between the strains [70,71]. According to the literature, E. coli B and K-12 derivatives are devoid of the O-antigen 
since, in both groups, IS elements are inserted at the gene clusters for O-antigen biosynthesis (within $w b b L$ in $\mathrm{K}-12$ and $w b b D$ in $E$. coli B). However, in the case of E. coli B derivatives, due to the IS1 insertion in waaT, the core part of LPS is further disrupted leading to the truncated core oligosaccharide [65].

Based on bioinformatics analysis, the tail fiber proteins of VpaE1 and their corresponding counterparts in other Felix01-related phages contain a conserved N-terminus (likely responsible for protein attachment to the phage particle) and a less-conserved C-terminal domain that may be responsible for the attachment of the virus to the host cell. Also, in the case of VpaE1_gp75 and its homologues, the region between the $\mathrm{N}$ - and C-terminal domains is highly variable in size and sequence.

Phylogenetic analysis based on the alignment of the amino acid sequences of putative tail fiber adhesins from various tailed viruses (Figure 9) revealed that the sequences of VpaE1_gp74 and vB_EcoM_AYO145A_gp077 are the most closely related, and both clustered on a separate divergent branch. The same was observed for the sequence of the C-terminal domain (238 aa) of gp75 of phage VpaE1 (VpaE1_gp75C).
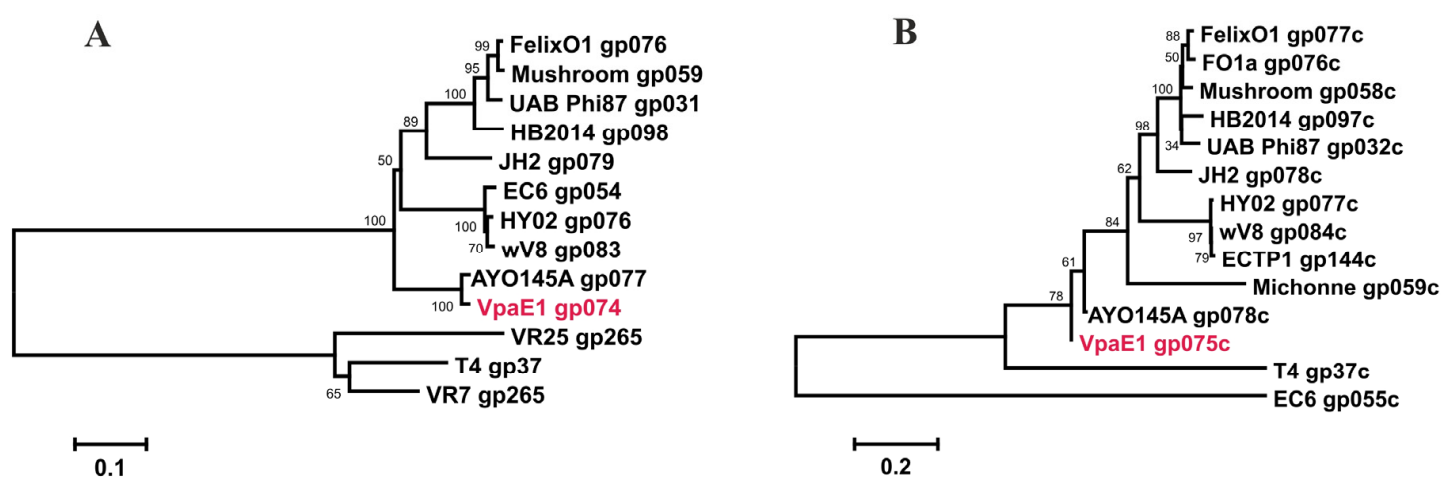

Figure 9. Phylogenetic analysis. Neighbor-joining trees were constructed based on the amino acid sequence alignment of VpaE1_gp74 (A) and VpaE1_gp75C (B) with tail fiber proteins from various myoviruses. The numbers at the nodes indicate the bootstrap probabilities.

As was mentioned above, gp74 and gp75 of VpaE1 both share a region of sequence similarity with gp37 of T4 yet, based on the results of phylogenetic analysis, these three proteins are only distantly related. Nevertheless, considering that both phages recognize E. coli B LPS but differ in their ability to use proteins as receptors, the adhesins of T4 and VpaE1 offer a promising model for studying protein structure-function relationship.

The majority of bacteriophages that belong to the newly proposed genus Felix01likevirus are highly virulent viruses, and have long been used in diverse applications, such as phage-based identification of bacteria, biocontrol of pathogens, phage-therapy, etc. [20,21,28,30,31,72]. Nevertheless, as is the case with antibiotics, the effectiveness of phage applications is greatly limited by the emergence of phage-resistant bacteria that often express rough or deep rough LPS. To surmount this obstacle, the use of phage cocktails that target multiple bacterial receptors has been proposed. In this regard, the isolation of truncated LPS-specific bacteriophages is of great importance.

\section{Conclusions}

Bacteriophage VpaE1 belongs to the newly proposed genus, Felix01likevirus, in the family Myoviridae. All Felix01-like viruses described to date are highly similar in genome structure and organization, and are adapted to infect O-Ag-expressing Salmonella or Escherichia coli strains. In contrast, phage VpaE1 presented here is the first Felix01-like virus that infects O-Ag-deficient E. coli strains with a truncated core LPS. Moreover, VpaE1 can replicate over a wide temperature range from 9 to $49^{\circ} \mathrm{C}$, suggesting that this phage is well adapted to harsh environmental conditions. Hence, bacteriophage VpaE1 shows potential for the development of phage-based applications. 
Supplementary Materials: The following are available online at http://www.mdpi.com/1999-4915/7/12/2932/s1, Table S1: List of annotated VpaE1 ORFs, Table S2: Data on proteomic analysis of VpaE1 virion proteins.

Acknowledgments: We would like to thank Audrius Driukas for assistance in VpaE1 isolation. We thank Lindsay W. Black, Kenneth N. Kreuzer, Edita Sužiedėliene and Jaunius Urbonavičius for bacterial strains. This research was funded by a grant (No. MIP-002/2014) from the Research Council of Lithuania.

Author Contributions: Eugenijus Šimoliūnas purified phage for TEM, and analyzed and annotated genome sequence; Monika Vilkaitytė performed adsorption tests and DNA restriction analysis; Laura Kalinienè analyzed phylogenetic relationships and wrote the paper; Aurelija Zajančkauskaitè performed host-range analysis; Algirdas Kaupinis performed LC MS/MS analysis; Juozas Staniulis executed TEM analysis; Mindaugas Valius contributed reagents and equipment and analyzed MS data; Rolandas Meškys contributed reagents and equipment, analyzed data, and advised on paper writing; and Lidija Truncaite conceived and designed the experiments, analyzed data and wrote the paper.

Conflicts of Interest: The authors declare no conflict of interest.

\section{References}

1. Rakhuba, D.V.; Kolomiets, E.I.; Dey, E.S.; Novik, G.I. Bacteriophage receptors, mechanisms of phage adsorption and penetration into host cell. Pol. J. Microbiol. 2010, 59, 145-155. [PubMed]

2. Shin, H.; Lee, J.H.; Kim, H.; Choi, Y.; Heu, S.; Ryu, S. Receptor diversity and host interaction of bacteriophages infecting Salmonella enterica serovar Typhimurium. PLoS ONE 2012, 7, e43392. [CrossRef] [PubMed]

3. Michel, A.; Clermont, O.; Denamur, E.; Tenaillon, O. Bacteriophage PhiX174‘s ecological niche and the flexibility of its Escherichia coli lipopolysaccharide receptor. Appl. Environ. Microbiol. 2010, 76, 7310-7313. [CrossRef] [PubMed]

4. Raetz, C.R.; Whitfield, C. Lipopolysaccharide endotoxins. Annu. Rev. Biochem. 2002, 71, 635-700. [CrossRef] [PubMed]

5. Hull, S. Escherichia coli lipopolysaccharide in pathogenesis and virulence. In Escherichia coli: Mechanisms of Virulence; Sussman, M., Ed.; Cambridge University Press: Cambridge, UK, 1997; pp. 145-167.

6. Amor, K.; Heinrichs, D.E.; Frirdich, E.; Ziebell, K.; Johnson, R.P.; Whitfield, C. Distribution of core oligosaccharide types in lipopolysaccharides from Escherichia coli. Infect. Immun. 2000, 68, 1116-1124. [CrossRef] [PubMed]

7. Kim, M.; Ryu, S. Spontaneous and transient defence against bacteriophage by phase-variable glucosylation of O-antigen in Salmonella enterica serovar Typhimurium. Mol. Microbiol. 2012, 86, 411-425. [CrossRef] [PubMed]

8. Labrie, S.J.; Samson, J.E.; Moineau, S. Bacteriophage resistance mechanisms. Nat. Rev. Microbiol. 2010, 8, 317-327. [CrossRef] [PubMed]

9. Perry, E.B.; Barrick, J.E.; Bohannan, B.J. The Molecular and genetic basis of repeatable coevolution between Escherichia coli and bacteriophage T3 in a laboratory microcosm. PLoS ONE 2015, 10, e0130639. [CrossRef] [PubMed]

10. Brockhurst, M.A.; Rainey, P.B.; Buckling, A. The effect of spatial heterogeneity and parasites on the evolution of host diversity. Proc. Biol. Sci. 2004, 271, 107-111. [CrossRef] [PubMed]

11. Buckling, A.; Wei, Y.; Massey, R.C.; Brockhurst, M.A.; Hochberg, M.E. Antagonistic coevolution with parasites increases the cost of host deleterious mutations. Proc. Biol. Sci. 2006, 273, 45-49. [CrossRef] [PubMed]

12. Yethon, J.A.; Heinrichs, D.E.; Monteiro, M.A.; Perry, M.B.; Whitfield, C. Involvement of waaY, waaQ, and waaP in the modification of Escherichia coli lipopolysaccharide and their role in the formation of a stable outer membrane. J. Biol. Chem. 1998, 273, 26310-26316. [CrossRef] [PubMed]

13. Yethon, J.A.; Vinogradov, E.; Perry, M.B.; Whitfield, C. Mutation of the lipopolysaccharide core glycosyltransferase encoded by waaG destabilizes the outer membrane of Escherichia coli by interfering with core phosphorylation. J. Bacteriol. 2000, 182, 5620-5623. [CrossRef] [PubMed]

14. Heinrichs, D.E.; Yethon, J.A.; Whitfield, C. Molecular basis for structural diversity in the core regions of the lipopolysaccharides of Escherichia coli and Salmonella enterica. Mol. Microbiol. 1998, 30, 221-232. [CrossRef] [PubMed] 
15. Marti, R.; Zurfluh, K.; Hagens, S.; Pianezzi, J.; Klumpp, J.; Loessner, M.J. Long tail fibres of the novel broad-host-range T-even bacteriophage S16 specifically recognize Salmonella OmpC. Mol. Microbiol. 2013, 87, 818-834. [CrossRef] [PubMed]

16. Kim, M.; Kim, S.; Park, B.; Ryu, S. Core lipopolysaccharide-specific phage SSU5 as an auxiliary component of a phage cocktail for Salmonella biocontrol. Appl. Environ. Microbiol. 2014, 80, 1026-1034. [CrossRef] [PubMed]

17. Bao, H.; Zhang, P.; Zhang, H.; Zhou, Y.; Zhang, L.; Wang, R. Bio-control of Salmonella enteritidis in foods using bacteriophages. Viruses 2015, 7, 4836-4853. [CrossRef] [PubMed]

18. Felix, A.; Callow, B.R. Typing of paratyphoid B bacilli by Vi bacteriophage. Brit. Med. J. 1943, 2, 127-130. [CrossRef] [PubMed]

19. Whichard, J.M.; Weigt, L.A.; Borris, D.J.; Li, L.L.; Zhang, Q.; Kapur, V.; Pierson, F.W.; Lingohr, E.J.; She, Y.M.; Kropinski, A.M.; et al. Complete genomic sequence of bacteriophage Felix O1. Viruses 2010, 2, 710-730. [CrossRef] [PubMed]

20. Hirsh, D.C.; Martin, L.D. Rapid detection of Salmonella spp. by using Felix-O1 bacteriophage and high-performance liquid chromatography. Appl. Environ. Microbiol 1983, 45, 260-264. [PubMed]

21. Whichard, J.M.; Sriranganathan, N.; Pierson, F.W. Suppression of Salmonella growth by wild-type and large-plaque variants of bacteriophage Felix $\mathrm{O} 1$ in liquid culture and on chicken frankfurters. J. Food Protect. 2003, 66, 220-225.

22. Lavigne, R.; Darius, P.; Summer, E.J.; Seto, D.; Mahadevan, P.; Nilsson, A.S.; Ackermann, H.W.; Kropinski, A.M. Classification of Myoviridae bacteriophages using protein sequence similarity. BMC Microbiol. 2009, 9. [CrossRef] [PubMed]

23. Villegas, A.; She, Y.M.; Kropinski, A.M.; Lingohr, E.J.; Mazzocco, A.; Ojha, S.; Waddell, T.E.; Ackermann, H.W.; Moyles, D.M.; Ahmed, R.; et al. The genome and proteome of a virulent Escherichia coli O157:H7 bacteriophage closely resembling Salmonella phage Felix O1. Virol. J. 2009, 6. [CrossRef] [PubMed]

24. Tiwari, B.R.; Kim, J. Complete genome sequence of bacteriophage EC6, capable of lysing Escherichia coli O157:H7. Genome Announc. 2013, 1, e00085-12. [CrossRef] [PubMed]

25. Hoa, N.X.; Tang, F.; Bai, Q.; Shen, C.; Vo, T.T.; Lu, C. Isolation and characterization of bacteriophages against enterotoxigenic Escherichia coli strains causing swine diseases. Afr. J. Microbiol. Res. 2013, 7, 2787-2793.

26. Cowley, L.A.; Beckett, S.J.; Chase-Topping, M.; Perry, N.; Dallman, T.J.; Gally, D.L.; Jenkins, C. Analysis of whole genome sequencing for the Escherichia coli O157:H7 typing phages. BMC Genom. 2015, 16. [CrossRef] [PubMed]

27. Wang, J.; Niu, Y.D.; Chen, J.; Anany, H.; Ackermann, H.W.; Johnson, R.P.; Ateba, C.N.; Stanford, K.; McAllister, T.A. Feces of feedlot cattle contain a diversity of bacteriophages that lyse non-O157 Shiga toxin-producing Escherichia coli. Can. J. Microbiol. 2015, 61, 467-475. [CrossRef] [PubMed]

28. Bardina, C.; Spricigo, D.A.; Cortes, P.; Llagostera, M. Significance of the bacteriophage treatment schedule in reducing Salmonella colonization of poultry. Appl. Environ. Microbiol. 2012, 78, 6600-6607. [CrossRef] [PubMed]

29. Moreno Switt, A.I.; Orsi, R.H.; den Bakker, H.C.; Vongkamjan, K.; Altier, C.; Wiedmann, M. Genomic characterization provides new insight into Salmonella phage diversity. BMC Genom. 2013, 14. [CrossRef] [PubMed]

30. Spricigo, D.A.; Bardina, C.; Cortes, P.; Llagostera, M. Use of a bacteriophage cocktail to control Salmonella in food and the food industry. Int. J. Food Microbiol. 2013, 165, 169-174. [CrossRef] [PubMed]

31. Colom, J.; Cano-Sarabia, M.; Otero, J.; Cortes, P.; Maspoch, D.; Llagostera, M. Liposome-encapsulated bacteriophages for enhanced oral phage therapy against Salmonella spp. Appl. Environ. Microbiol. 2015, 81, 4841-4849. [CrossRef] [PubMed]

32. Tolen, T.N.; Xie, Y.; Hernandez, A.C.; Kuty Everett, G.F. Complete genome sequence of Salmonella enterica serovar Typhimurium myophage mushroom. Genome Announc. 2015, 3, e00154-15. [CrossRef] [PubMed]

33. Lehman, S.M.; Kropinski, A.M.; Castle, A.J.; Svircev, A.M. Complete genome of the broad-host-range Erwinia amylovora phage phiEa21-4 and its relationship to Salmonella phage felix O1. Appl. Environ. Microbiol. 2009, 75, 2139-2147. [CrossRef] [PubMed]

34. Nguyen, Q.T.; Luna, A.J.; Hernandez, A.C.; Kuty Everett, G.F. Complete genome sequence of Citrobacter freundii myophage Moogle. Genome Announc. 2015, 3, e01426-14. [CrossRef] [PubMed] 
35. Henry, M.; Bobay, L.M.; Chevallereau, A.; Saussereau, E.; Ceyssens, P.J.; Debarbieux, L. The search for therapeutic bacteriophages uncovers one new subfamily and two new genera of Pseudomonas-infecting Myoviridae. PLoS ONE 2015, 10, e0117163. [CrossRef] [PubMed]

36. Baba, T.; Ara, T.; Hasegawa, M.; Takai, Y.; Okumura, Y.; Baba, M.; Datsenko, K.A.; Tomita, M.; Wanner, B.L.; Mori, H. Construction of Escherichia coli K-12 in-frame, single-gene knockout mutants: the Keio collection. Mol. Syst. Biol. 2006, 2. [CrossRef] [PubMed]

37. Simpson, D.J.; Sacher, J.C.; Szymanski, C.M. Exploring the interactions between bacteriophage-encoded glycan binding proteins and carbohydrates. Curr. Opin. Struct. Biol. 2015, 34, 69-77. [CrossRef] [PubMed]

38. Kutter, E. Phage host range and efficiency of plating. In Bacteriophages: Methods in Molecular Biology; Clokie, M.R.J., Kropinski, A.M., Eds.; Humana Press: New York, NY, USA, 2009; Volume 1, pp. 141-149.

39. Kropinski, A.M. Measurement of the bacteriophage inactivation kinetics with purified receptors. In Bacteriophages: Methods in Molecular Biology; Clokie, M.R.J., Kropinski, A.M., Eds.; Humana Press: New York, NY, USA, 2009; Volume 1, pp. 157-160.

40. Kiljunen, S.; Datta, N.; Dentovskaya, S.V.; Anisimov, A.P.; Knirel, Y.A.; Bengoechea, J.A.; Holst, O.; Skurnik, M. Identification of the lipopolysaccharide core of Yersinia pestis and Yersinia pseudotuberculosis as the receptor for bacteriophage phiA1122. J. Bacteriol. 2011, 193, 4963-4972. [CrossRef] [PubMed]

41. Delcher, A.L.; Harmon, D.; Kasif, S.; White, O.; Salzberg, S.L. Improved microbial gene identification with GLIMMER. Nucleic Acids Res. 1999, 27, 4636-4641. [CrossRef] [PubMed]

42. Kearse, M.; Moir, R.; Wilson, A.; Stones-Havas, S.; Cheung, M.; Sturrock, S.; Buxton, S.; Cooper, A.; Markowitz, S.; Duran, C.; et al. Geneious basic: An integrated and extendable desktop software platform for the organization and analysis of sequence data. Bioinformatics 2012, 28, 1647-1649. [CrossRef] [PubMed]

43. Schattner, P.; Brooks, A.N.; Lowe, T.M. The tRNAscan-SE, snoscan and snoGPS web servers for the detection of tRNAs and snoRNAs. Nucleic Acids Res. 2005, 33, W686-W689. [CrossRef] [PubMed]

44. Tamura, K.; Peterson, D.; Peterson, N.; Stecher, G.; Nei, M.; Kumar, S. MEGA5: Molecular evolutionary genetics analysis using maximum likelihood, evolutionary distance, and maximum parsimony methods. Mol. Biol. Evol. 2011, 28, 2731-2739. [CrossRef] [PubMed]

45. Laemmli, U.K. Cleavage of structural proteins during the assembly of the head of bacteriophage T4. Nature 1970, 227, 680-685. [CrossRef] [PubMed]

46. Feist, P.; Hummon, A.B. Proteomic challenges: Sample preparation techniques for microgram-quantity protein analysis from biological samples. Int. J. Mol. Sci. 2015, 16, 3537-3563. [CrossRef] [PubMed]

47. Wisniewski, J.R.; Zougman, A.; Nagaraj, N.; Mann, M. Universal sample preparation method for proteome analysis. Ant. Methods 2009, 6, 359-362. [CrossRef] [PubMed]

48. Kaliniene, L.; Klausa, V.; Truncaite, L. Low-temperature T4-like coliphages vB_EcoM-VR5, vB_EcoM-VR7 and vB_EcoM-VR20. Arch. Virol. 2010, 155, 871-880. [CrossRef] [PubMed]

49. Kaliniene, L.; Klausa, V.; Zajanckauskaite, A.; Nivinskas, R.; Truncaite, L. Genome of low-temperature T4-related bacteriophage vB_EcoM-VR7. Arch. Virol. 2011, 156, 1913-1916. [CrossRef] [PubMed]

50. Kaliniene, L.; Zajanckauskaite, A.; Simoliunas, E.; Truncaite, L.; Meskys, R. Low-temperature bacterial viruses VR-A small but diverse group of E. coli phages. Arch. Virol. 2015, 160, 1367-1370. [CrossRef] [PubMed]

51. Truncaite, L.; Simoliunas, E.; Zajanckauskaite, A.; Kaliniene, L.; Mankeviciute, R.; Staniulis, J.; Klausa, V.; Meskys, R. Bacteriophage vB_EcoM_FV3: A new member of "rV5-like viruses". Arch. Virol. 2012, 157, 2431-2435. [CrossRef] [PubMed]

52. Selick, H.E.; Kreuzer, K.N.; Alberts, B.M. The bacteriophage T4 insertion/substitution vector system. A method for introducing site-specific mutations into the virus chromosome. J. Biol. Chem. 1988, 263, 11336-11347. [PubMed]

53. Grenier, F.; Matteau, D.; Baby, V.; Rodrigue, S. Complete genome sequence of Escherichia coli BW25113. Genome Announc. 2014, 2, e01038-14. [CrossRef] [PubMed]

54. Simoliunas, E.; Kaliniene, L.; Truncaite, L.; Klausa, V.; Zajanckauskaite, A.; Meskys, R. Genome of Klebsiella sp.-infecting bacteriophage vB_KleM_RaK2. J. Virol. 2012, 86. [CrossRef] [PubMed]

55. Hyman, P.; Abedon, S.T. Bacteriophage host range and bacterial resistance. In Advances in Applied Microbiology; Laskin, A.I., Sariaslani, S., Gadd, G.M., Eds.; Elsevier Inc. Academic Press: Burlington, MA, USA, 2010; Volume 70, pp. 217-248. 
56. Dy, R.L.; Richter, C.; Salmond, G.P.; Fineran, P.C. Remarkable mechanisms in microbes to resist phage infections. Annu. Rev. Virol. 2014, 1, 307-331. [CrossRef]

57. Lavigne, R.; Noben, J.P.; Hertveldt, K.; Ceyssens, P.J.; Briers, Y.; Dumont, D.; Roucourt, B.; Krylov, V.N.; Mesyanzhinov, V.V.; Robben, J.; et al. The structural proteome of Pseudomonas aeruginosa bacteriophage phiKMV. Microbiology 2006, 152, 529-534. [CrossRef] [PubMed]

58. Lavigne, R.; Ceyssens, P.J.; Robben, J. Phage proteomics: Applications of mass spectrometry. In Bacteriophages: Methods in Molecular Biology; Clockie, M.R.J., Kropinski, A.M., Eds.; Humana Press: Totowa, NJ, USA, 2009; Volume 2, pp. 239-251.

59. Pupo, G.M.; Karaolis, D.K.; Lan, R.; Reeves, P.R. Evolutionary relationships among pathogenic and nonpathogenic Escherichia coli strains inferred from multilocus enzyme electrophoresis and mdh sequence studies. Infect. Immun. 1997, 65, 2685-2692. [PubMed]

60. Reid, S.D.; Herbelin, C.J.; Bumbaugh, A.C.; Selander, R.K.; Whittam, T.S. Parallel evolution of virulence in pathogenic Escherichia coli. Nature 2000, 406, 64-67. [PubMed]

61. Hayashi, T.; Makino, K.; Ohnishi, M.; Kurokawa, K.; Ishii, K.; Yokoyama, K.; Han, C.G.; Ohtsubo, E.; Nakayama, K.; Murata, T.; et al. Complete genome sequence of enterohemorrhagic Escherichia coli O157:H7 and genomic comparison with a laboratory strain K-12. DNA Res. 2001, 8, 11-22. [CrossRef] [PubMed]

62. Wang, Z.; Wang, J.; Ren, G.; Li, Y.; Wang, X. Influence of core oligosaccharide of lipopolysaccharide to outer membrane behavior of Escherichia coli. Mar. Drugs 2015, 13, 3325-3339. [CrossRef] [PubMed]

63. Frirdich, E.; Lindner, B.; Holst, O.; Whitfield, C. Overexpression of the waaZ gene leads to modification of the structure of the inner core region of Escherichia coli lipopolysaccharide, truncation of the outer core, and reduction of the amount of $\mathrm{O}$ polysaccharide on the cell surface. J. Bacteriol. 2003, 185, 1659-1671. [CrossRef] [PubMed]

64. Taylor, C.M.; Goldrick, M.; Lord, L.; Roberts, I.S. Mutations in the waaR gene of Escherichia coli which disrupt lipopolysaccharide outer core biosynthesis affect cell surface retention of group 2 capsular polysaccharides. J. Bacteriol. 2006, 188, 1165-1168. [CrossRef] [PubMed]

65. Jeong, H.; Barbe, V.; Lee, C.H.; Vallenet, D.; Yu, D.S.; Choi, S.H.; Couloux, A.; Lee, S.W.; Yoon, S.H.; Cattolico, L.; et al. Genome sequences of Escherichia coli B strains REL606 and BL21(DE3). J. Mol. Biol. 2009, 394, 644-652. [CrossRef] [PubMed]

66. Qian, J.; Garrett, T.A.; Raetz, C.R. In vitro assembly of the outer core of the lipopolysaccharide from Escherichia coli K-12 and Salmonella typhimurium. Biochemistry 2014, 53, 1250-1262. [CrossRef] [PubMed]

67. Kaszowska, M.; Niedziela, T.; Maciejewska, A.; Lukasiewicz, J.; Jachymek, W.; Lugowski, C. Core oligosaccharide of Escherichia coli B-the structure required for bacteriophage T4 recognition. Carbohydr. Res. 2015, 413, 51-54. [CrossRef] [PubMed]

68. Yu, F.; Mizushima, S. Roles of lipopolysaccharide and outer membrane protein OmpC of Escherichia coli $\mathrm{K}-12$ in the receptor function for bacteriophage T4. J. Bacteriol. 1982, 151, 718-722. [PubMed]

69. Studier, F.W.; Daegelen, P.; Lenski, R.E.; Maslov, S.; Kim, J.F. Understanding the differences between genome sequences of Escherichia coli B strains REL606 and BL21(DE3) and comparison of the E. coli B and K-12 genomes. J. Mol. Biol. 2009, 394, 653-680. [CrossRef] [PubMed]

70. Schneider, D.; Duperchy, E.; Depeyrot, J.; Coursange, E.; Lenski, R.E.; Blot, M. Genomic comparisons among Escherichia coli strains B, K-12, and O157: H7 using IS elements as molecular markers. BMC Microbiol. 2002, 2. [CrossRef]

71. Yoon, S.H.; Han, M.J.; Jeong, H.; Lee, C.H.; Xia, X.X.; Lee, D.H.; Shim, J.H.; Lee, S.Y.; Oh, T.K.; Kim, J.F. Comparative multi-omics systems analysis of Escherichia coli strains B and K-12. Genome Biol. 2012, 13. [CrossRef]

72. Niu, Y.D.; Johnson, R.P.; Xu, Y.; McAllister, T.A.; Sharma, R.; Louie, M.; Stanford, K. Host range and lytic capability of four bacteriophages against bovine and clinical human isolates of Shiga toxin-producing Escherichia coli O157:H7. J. Appl. Microbiol. 2009, 107, 646-656. [CrossRef] [PubMed]

(C) 2015 by the authors; licensee MDPI, Basel, Switzerland. This article is an open access article distributed under the terms and conditions of the Creative Commons by Attribution (CC-BY) license (http:/ / creativecommons.org/licenses/by/4.0/). 